\title{
Use of bone mesenchymal stem cells to treat rats with acute liver failure
}

\author{
S.F. Yuan ${ }^{1,2}$, T. Jiang ${ }^{3}$, L.H. Sun ${ }^{1}$, R.J. Zheng', G.Q. Cao ${ }^{2}$, N.Z. Ahat ${ }^{4}$ \\ and Y.X. Zhang ${ }^{1}$ \\ ${ }^{1}$ Department of Infectious Diseases, \\ First Affiliated Hospital of Xinjiang Medical University, Xinjiang, \\ Xinjiang Province, China \\ ${ }^{2}$ Fifth Affiliated Hospital of Xinjiang Medical University, Xinjiang, \\ Xinjiang Province, China \\ ${ }^{3}$ Key Laboratory of Xinjiang Medical Animal Model Research, \\ Xinjiang, Xinjiang Province, China \\ ${ }^{4}$ College of Life Science and Technology of Xinjiang University, \\ Xinjiang, Xinjiang Province, China \\ Corresponding author: Y.X. Zhang \\ E-mail: yuanshufen@163.com / zhangyx3103@163.com
}

Genet. Mol. Res. 13 (3): 6962-6980 (2014)

Received April 11, 2013

Accepted August 27, 2013

Published April 30, 2014

DOI http://dx.doi.org/10.4238/2014.April.30.10

\begin{abstract}
This study aimed to isolate mesenchymal stem cells from bone mesenchymal stem cells (BMSCs), determine their therapeutic potential for treating rats with acute liver failure (ALF), further explore the factors that induce liver failure mechanisms, and elucidate the role of bone marrow stem cell therapy and BMSCs on liver homing. We found that differentiation potential was present in BMSCs expressing high levels of CD29 and CD90. These cells improved liver functioning in vivo after transplantation into rat livers with D-galactosamine damage, as evidenced by the levels of alanine aminotransferase and aspartate aminotransferase returning to normal (low levels) in recipient ALF rats. A significant improvement in the liver functional test and histological findings was observed in the
\end{abstract}


transplantation group after 120 and $168 \mathrm{~h}$ of transplantation $(\mathrm{P}<0.05)$. Histological data revealed that hepatocyte cell apoptosis was lower in the transplantation group compared to the control groups $(\mathrm{P}<0.05)$, and that the transplantation of BMSCs reduced liver inflammation, decreased hepatic denaturation and necrosis, and promoted liver regeneration. These ameliorations were not recorded in the control groups. The results of in situ hybridization, immunofluorescence staining, and Western blot confirmed the presence of transplanted BMSCs in recipient rat livers. Stromal cell derived factor-1 alpha and vascular endothelial growth factor were significantly upregulated after the intraportal transplantation of BMSCs, with significantly higher levels being found in the portal vein and the tail vein groups $(\mathrm{P}<0.05)$. In conclusion, BMSCs have a therapeutic effect against ALF rats, evoke endogenous repair mechanisms in the liver, and may represent a novel form of therapeutic intervention for the disease. Furthermore, intraportal transplantation serves as a more effective pathway compared to tail vein transplantation.

Key words: Acute liver failure; Cell transplantation; Bone mesenchymal stem cells; Portal venous transplantation; Stromal cell derived factor-1 alpha; Vascular endothelial growth factor

\section{INTRODUCTION}

Acute liver failure (ALF) is defined as the rapid development of severe acute liver injury with impaired synthetic function and hepatic encephalopathy in the absence of pre-existing liver diseases. The disease causes high morbidity and mortality. Orthotopic liver transplantation is the most effective therapy for ALF; however, it is very costly, highly intrusive, irreversible, limited by a shortage of donor organs, and requires life-long immunosuppressive treatments (Lee et al., 2008; Kim and Kremers, 2008). Thus, it is imperative to develop new approaches for repairing the liver. At present, mesenchymal stem cells represent an alternate cell source to substitute primary hepatocytes in hepatocyte transplantation, because of their multiple differentiation potential and nearly unlimited availability. Mesenchymal stem cells have been shown to differentiate into hepatocyte-like cells in vitro and also maintain specific hepatocyte functions after transplantation into the livers of damaged and control mice and rats. Depending on the underlying liver disease, mesenchymal stem cells either replace the diseased liver tissue or support liver regeneration through anti-inflammatory, anti-apoptotic, and proliferative actions (Enns and Millan, 2008; Lysy et al., 2008; Oertel and Shafritz, 2008; Alison et al., 2009; Stutchfield et al., 2010).

Recent studies using experimental animal models and samples from clinical mobilization protocols have demonstrated that chemokines, such as stromal cell derived factor- $1 \alpha$ (SDF$1 \alpha$ ), are involved in the mobilization process (Askari et al., 2003; Masson et al., 2004). SDF-1 $\alpha$ promotes the homing of bone marrow stem cells to tissue injury and repair. Vascular endothelial growth factor (VEGF) is an important growth factor involved in angiogenesis. It is a multifunctional protein that has several effects on endothelial cells that promote the formation of new 
vessels. Furthermore, VEGF stimulates the production of hepatocyte growth factor, which is regarded as an initiator of liver regeneration (Los et al., 2005). Therefore, at present, much research is focusing on the expression of SDF-1 $\alpha$ and VEGF in ALF to observe the efficiency of homing stem cells and the tissue repair of injury.

In the present study, we observed the effects of bone mesenchymal stem cell (BMSC) transplantation in rats with ALF and explored the relevant mechanisms involving SDF-1 $\alpha$ and VEGF. Through detecting the expression of SDF- $1 \alpha$ and VEGF in liver, help and understanding the factors that influence the homing distribution of bone marrow, we aimed to provide an experimental basis for the clinical development of BMSC transplantation in the treatment of ALF.

\section{MATERIAL AND METHODS}

\section{Isolation, culture, and identification of BMSCs from rats}

Healthy male Sprague-Dawley rats (8 weeks old and weighing around $200 \mathrm{~g}$; specific pathogen free) were provided by the Disease Control Center of Animals in Xinjiang, China (License No. SCXK new 2003-0002). BMSCs were isolated by using the method of stick wall separation, external training, and appraisal. After the intraperitoneal injection of 50,000 U heparin, the rats were sacrificed after $15 \mathrm{~min}$. Subsequently, whole bone marrow of the bilateral tibia was collected and $1 \times 10^{9}$ cells/L were seeded on $75-\mathrm{cm}^{2}$ Petri dishes. After $24 \mathrm{~h}$, the medium was changed to remove nonadherent cells. Many colonies had formed approximately 7-10 days later. After achieving 70-80\% confluence, the adherent cells were trypsinized using $0.25 \%(\mathrm{w} / \mathrm{v})$ trypsin/EDTA (Invitrogen, Carlsbad, CA, USA), and were replated at a 1:3 dilution. The BMSCs at the 3rd passage were identified and cultured for future experiments. The cultured BMSCs were resuspended at a concentration of $1.4 \times 10^{7}$ cells $/ \mathrm{kg}$ in saline for transplantation.

\section{Flow cytometry}

The cultured cells were trypsinized and resuspended in PBS containing 1\% bovine serum albumin (BSA). Cell suspensions were incubated with different antibodies, including FITC-labeled anti-rat CD45, CD29, CD11, and CD90 (Sato et al., 2005; Cho et al., 2009) (all from BioLegend, USA), at a recommended dilution (1:100) for $30 \mathrm{~min}$ at room temperature in the dark. Isotype-identical antibodies (IgG) served as controls. After staining, the cells were fixed with $1 \%$ paraformaldehyde. Positive cells were counted by flow cytometry by utilizing a fluorescence-activated cell sorter (Beckman Coulter FC500 Flow Cytometer, USA) in duplicate, with the mean being reported.

\section{Animal model of liver injury and treatments}

A total of 80 rats were placed in cages at $24^{\circ} \mathrm{C}$ with a 12 -h light-dark cycle, and allowed free access to water and food. All experiments were approved by the Medical Ethics Committee of Xinjiang Medical University, Xinjiang, China, and the Principles of Laboratory Animal Care in the University were followed. The ALF model was induced by 2 intraperitoneal injections of $1.4 \mathrm{~g} / \mathrm{kg} 10 \%$ D-galactosamine in $12 \mathrm{~h}$ and $20 \mu \mathrm{g} / \mathrm{kg} 0.005 \%$ lipopolysaccha- 
ride (LPS) once in $12 \mathrm{~h}$. Subsequently, the rats were subjected to an allograft transplantation of BMSCs through either portal vein or tail vein injection. The control group was given no treatment. Blood samples and liver tissue specimens were collected after 24, 72, 120, and 168 $\mathrm{h}$ of transplantation. Liver tissue was collected after being fixed with $4 \%$ paraformaldehyde solution, and was then preserved in formalin buffer solution for subsequent histopathological studies. For protein and total RNA isolation, the liver tissue was snap-frozen in liquid nitrogen and then stored at $-80^{\circ} \mathrm{C}$.

Samples of 5 normal rats were used to define the normal control range of alanine aminotransferase (ALT), aspartate aminotransferase (AST), and albumin. A total of 75 rats presenting abnormal ALT and AST were randomly assigned to 3 groups at $24 \mathrm{~h}$ after D-galactosamine and LPS injection. Group A contained the control group without transplantation. Group B contained the portal vein group, in which rats were anesthetized and subjected to an upper midline incision inferiorly from the xiphoid, and the abdominal cavity was exposed with a retractor. The portal vein was gently isolated and directly injected with $1.4 \times 10^{7}$ cells $/ \mathrm{kg}$ BMSCs using a 25 -gauge needle connected to a $2-\mathrm{mL}$ syringe (Sato et al., 2005; Cho et al., 2009). The abdominal wall was closed after bleeding was stopped by pressure. Group $\mathrm{C}$ contained the tail vein group, in which $1.4 \times 10^{7}$ cells $/ \mathrm{kg}$ BMSCs were injected into the tail vein.

\section{Biochemical analysis}

Serum was separated by centrifugation within $1 \mathrm{~h}$ of blood collection when the rats were sacrificed. The serum was then stored at $-80^{\circ} \mathrm{C}$ until further analysis. The serum levels of AST and ALT rats were determined using an Automated Chemical Analyzer (Unicel Dxc 800; Beckman Coulter), following manufacturer protocols. The density of serum AST and ALT activity in the experimental and control groups was compared. The serum levels of AST and ALT in the experimental and control groups were measured at 24, 72, 120, and $168 \mathrm{~h}$ after BMSC transplantation.

\section{Histology}

Liver tissues were fixed, embedded in paraffin, and sectioned to assess the degree of liver injury. The livers were fixed in $4 \%$ paraformaldehyde, dehydrated using graded ethanol, and then embedded in paraffin. The paraffin blocks were sectioned and stained with hematoxylin and eosin (HE) using standard histological techniques. Histological analysis was conducted by a single-blind pathologist (i.e., who had not had prior access to the samples). Five non-overlapping fields that were randomly selected per section were analyzed at $100 \mathrm{x}$ final magnification (BX50 Microscope, OlymPus Company, Japan).

\section{Analysis of hepatocyte cell apoptosis}

Paraffin sections were routinely deparaffinized and rehydrated. Apoptosis was determined by the in situ detection of DNA fragmentation using terminal deoxynucleotidyl transferase-mediated 2'-deoxyuridine 5'-triphosphate nick-end labeling (TUNEL, Roche Applied Science) assay, following manufacturer protocols. Quantification of TUNEL-positive hepatocyte nuclei was assessed by calculating the mean of the number of TUNEL-positive hepatocytes in 10 random $200 \mathrm{X}$ fields per animal. 


\section{Immunofluorescence staining}

For the immunofluorescence assay, paraffin-fixed liver tissue was divided into 5- $\mu \mathrm{m}$ sections, and then the sections were deparaffinized and hydrated. After treatment with $0.3 \%$ $\mathrm{H}_{2} \mathrm{O}_{2}$ in methanol for 10 min to inhibit endogenous peroxidase activity, the sections were blocked using BSA. The blocked sections were incubated overnight at $4^{\circ} \mathrm{C}$ with mouse VEGF antibody (1:1000, ab1316; Abcam Inc., USA). Then, the sections were incubated with FITCconjugated secondary antibodies (Thermo Scientific, cat\#, MH14501415; Pierce Biotechnology, Rockford, IL, USA) for 15 min. After staining the nucleus with 4',6-diamidine-2'-phenylindole (DAPI), it was immediately observed under a fluorescent microscope. The total number of fluorescence-labeled cells in each section was calculated.

\section{In situ hybridization}

In situ hybridization was measured to determine the expression of SDF-1 $\alpha$ mRNA (MK2121, Bo Shi De, China). Liver biopsy tissues were dewaxed with xylene, and hydrated with decreasing concentrations of ethanol. The tissue was post-fixed in $4 \%$ paraformaldehyde in PBS for $20 \mathrm{~min}$ and treated with proteinase $\mathrm{K}(20 \mu \mathrm{g} / \mathrm{mL}$ in $50 \mathrm{mM}$ Tris, $5 \mathrm{mM}$ EDTA) for $10 \mathrm{~min}$ at $37^{\circ} \mathrm{C}$. The sections were treated again with $4 \%$ paraformaldehyde in PBS and acetylated (100 mM triethanolamine, $25 \mathrm{mM}$ acetic anhydride). After dehydration with ethanol, the sections were hybridized at $55^{\circ} \mathrm{C}$ for $18 \mathrm{~h}$ with digoxigenin-labeled sense and antisense probes at a concentration of $10 \mathrm{ng} / \mathrm{mL}$. After hybridization, the slides were washed in 5X SSC and 10 $\mathrm{mM}$ dithiothreitol at $50^{\circ} \mathrm{C}$, followed by $2 \mathrm{X}$ SSC containing $100 \mathrm{mM}$ dithiothreitol and $50 \%$ formamide at $65^{\circ} \mathrm{C}$ for $20 \mathrm{~min}$. The sections were then treated for $30 \mathrm{~min}$ with RNAse A ( $20 \mu \mathrm{g} /$ $\mathrm{mL}$ ) in $10 \mathrm{mM}$ Tris, $5 \mathrm{mM}$ EDTA, and $0.5 \mathrm{mM} \mathrm{NaCl}$ at $37^{\circ} \mathrm{C}$. After washing each slide in 2 and $0.1 \mathrm{X} \mathrm{SSC}$ for $30 \mathrm{~min}$ at $65^{\circ} \mathrm{C}$, the digoxigenin-labeled probe was detected immunohistochemically (Nonradioactive Detection Kit, Boehringer Mannheim Biochemicals, Indianapolis, IN, USA), and the tissue sections were counterstained with Mayer's hematoxylin.

\section{Western blot}

Frozen liver tissue was homogenized in lysis buffer (150 mM NaCl, $10 \mathrm{mM}$ HEPES, 1 mM EDTA, $0.5 \mathrm{mM}$ phenylmethylsulfonyl fluoride, and $0.6 \%$ Nonidet P-40). The samples were sonicated for $15 \mathrm{~s}$, and then centrifuged at $3000 \mathrm{rpm}$ at $4^{\circ} \mathrm{C}$ for $15 \mathrm{~min}$. The supernatants were transferred to clean tubes, and the total protein was determined by a BCA protein assay. Forty micrograms of protein was separated on a $12 \%$ SDS gel run at $200 \mathrm{~V}$ for $60 \mathrm{~min}$. After electrophoresis, the protein was transferred to a polyvinylidene fluoride membrane. The membrane was incubated overnight at $4^{\circ} \mathrm{C}$ with SDF-1 $\alpha$ (1:1000; Thermo Scientific PA5-17238, Pierce Biotechnology), VEGF (1:1000, ab1316), and glyceraldehyde-3-phosphate dehydrogenase (GAPDH) (1:2000, sc-25778; Santa Cruz Biotechnology, Inc., USA) antibodies appropriately diluted in $1 \mathrm{X}$ TBST containing $5 \%$ nonfat dry milk. The membrane was then processed with HRP-conjugated goat anti-rabbit IgG or goat anti-mouse IgG (Thermo Scientific ND172675; Pierce Biotechnology), and the immune complexes were visualized using the enhanced chemiluminescence system (Amersham Biosciences). The band intensities were measured using the Quantity One Analysis Software, and were calculated as the ratios to GAPDH. 


\section{Statistical analysis}

Data are reported as means $\pm \mathrm{SD}$. The differences between the groups were compared with the $t$-test and multiple factor analysis of variance. Correlation analysis was carried out using Pearson correlation analysis. A value of $\mathrm{P}<0.05$ was considered to be statistically significant. All data were processed using the statistical package SPSS 18.0 software.

\section{RESULTS}

\section{Isolation and identification of BMSCs}

BMSCs were isolated from Sprague-Dawley rats, and the proliferating cells were enriched. After about 7-10 days, the Petri dishes were full of BMSCs, forming cell clusters or cell monolayers that covered the bottom of the container and were arranged in radial concentric circles or peak valley-like growths. The cell clusters exhibited synchronicity and contraction (Figure 1).
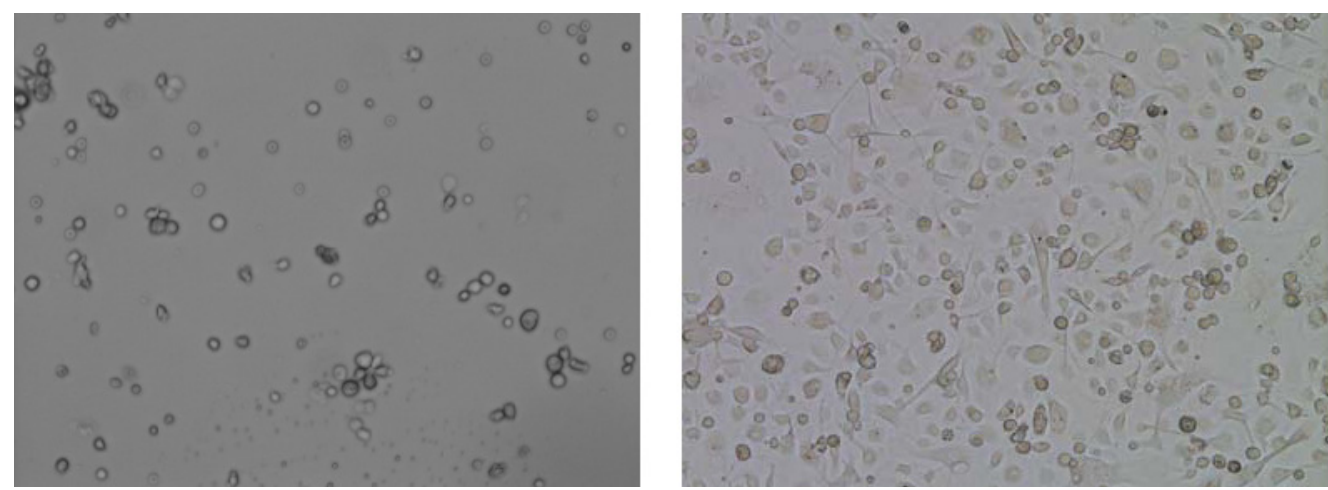

Figure 1. Flow cytometric characterization of bone mesenchymal stem cells (magnification 100X).

The BMSCs were identified by flow cytometry. BMSCs were incubated with FITCconjugated antibodies. Primary rat BMSCs positively expressed MSC-specific markers, CD29 $(+)$ and CD90 (+), but negatively expressed CD11 and CD45 (Figure 2). Thus, the bone marrow cells were of high purity after the 3rd passage and expressed CD29+, CD90+, CD11-, and CD45-, which are BMSC markers.

\section{Effects of BMSC transplantation on liver function tests}

Our laboratory findings indicated the protection capability of BMSCs. ALT and AST serum levels of the experimental and control groups were measured by an automatic biochemistry analyzer (Unicel Dxc 800; Beckman Coulter). ALT and AST serum levels were significantly higher in the ALF models. After 120 and $168 \mathrm{~h}$ of BMSC transplantation, there was a significant decline in ALT and AST levels. Subsequently, ALT and AST serum 
levels in the transplantation groups were measured $(\mathrm{P}<0.05 v s$ the control group) (Table 1). The density of serum ALT and AST noticeably changed after BMSC transplantation, which confirmed that transplanted BMSCs ameliorate liver function. ALT and AST serum levels declined more in the portal vein group compared to the tail vein group; however, these differences between the portal vein group and the tail vein group were not significant (Figures 3 and 4).

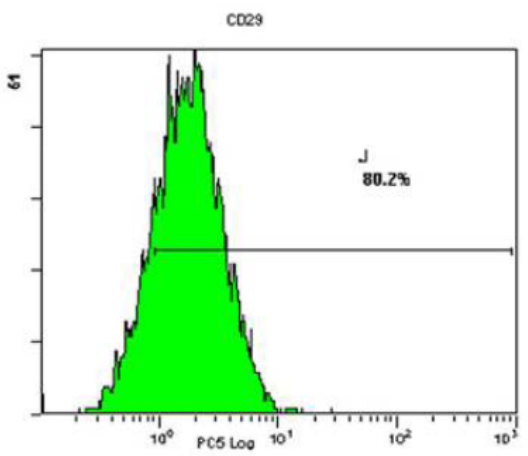

$\mathrm{PE} / \mathrm{CyCD} 29$

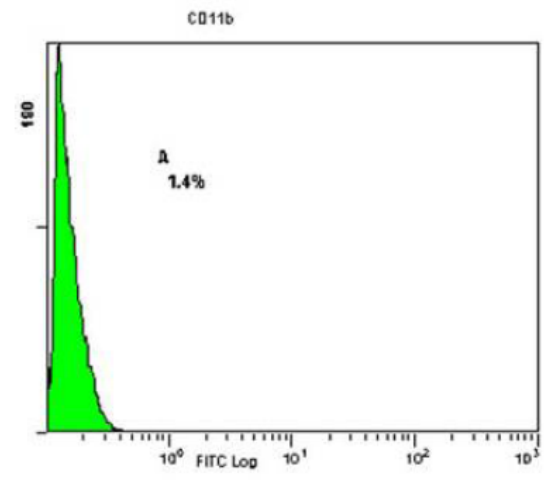

FITC CD11B/c

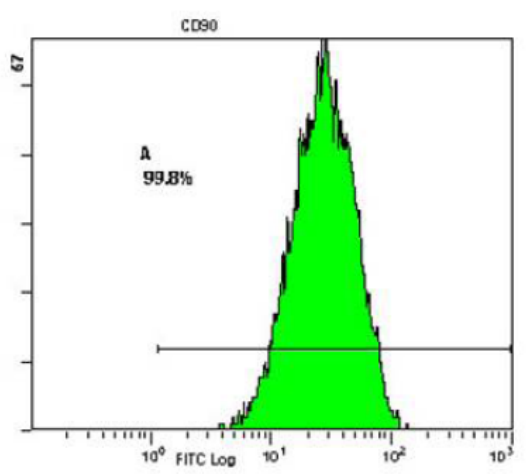

FITC CD90

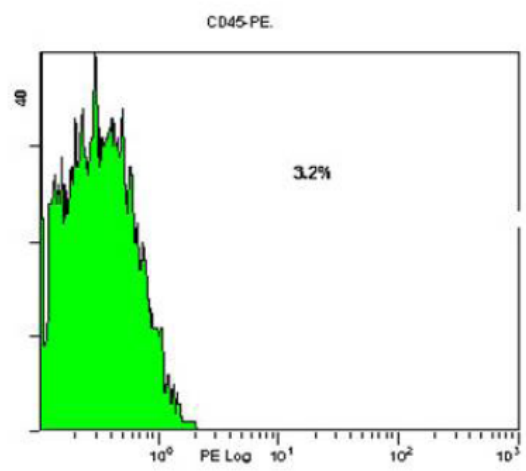

PECD45

Figure 2. Morphology characteristics of rat bone marrow menchymal stem cells.

Table 1. Comparison of liver function by two transplantation ways in acute liver failure (IU/L).

\begin{tabular}{|c|c|c|c|c|c|c|}
\hline \multirow[t]{2}{*}{ Group } & \multicolumn{2}{|c|}{$24 \mathrm{~h}$} & \multicolumn{2}{|c|}{$120 \mathrm{~h}$} & \multicolumn{2}{|c|}{$168 \mathrm{~h}$} \\
\hline & ALT & AST & ALT & AST & ALT & AST \\
\hline Control group & $132.20 \pm 50.37$ & $168.00 \pm 88.24$ & $140.50 \pm 47.33$ & $175.50 \pm 99.27$ & $145.40 \pm 31.41$ & $183.20 \pm 61.07$ \\
\hline Tail vein group & $128.25 \pm 68.08$ & $173.50 \pm 93.10$ & $94.17 \pm 13.29^{\mathrm{a}}$ & $112.83 \pm 18.20^{\mathrm{a}}$ & $74.33 \pm 13.81^{\mathrm{a}}$ & $95.50 \pm 13.84^{\mathrm{a}}$ \\
\hline Portal vein group & $136.40 \pm 54.05$ & $177.20 \pm 88.25$ & $77.83 \pm 6.49^{b}$ & $97.50 \pm 14.78^{b}$ & $46.00 \pm 8.70^{\mathrm{b}}$ & $72.67 \pm 25.75^{b}$ \\
\hline
\end{tabular}

${ }^{\mathrm{a}} \mathrm{P}<0.05 v s$ control group, ${ }^{\text {}} \mathrm{P}<0.05$ vs control group. 


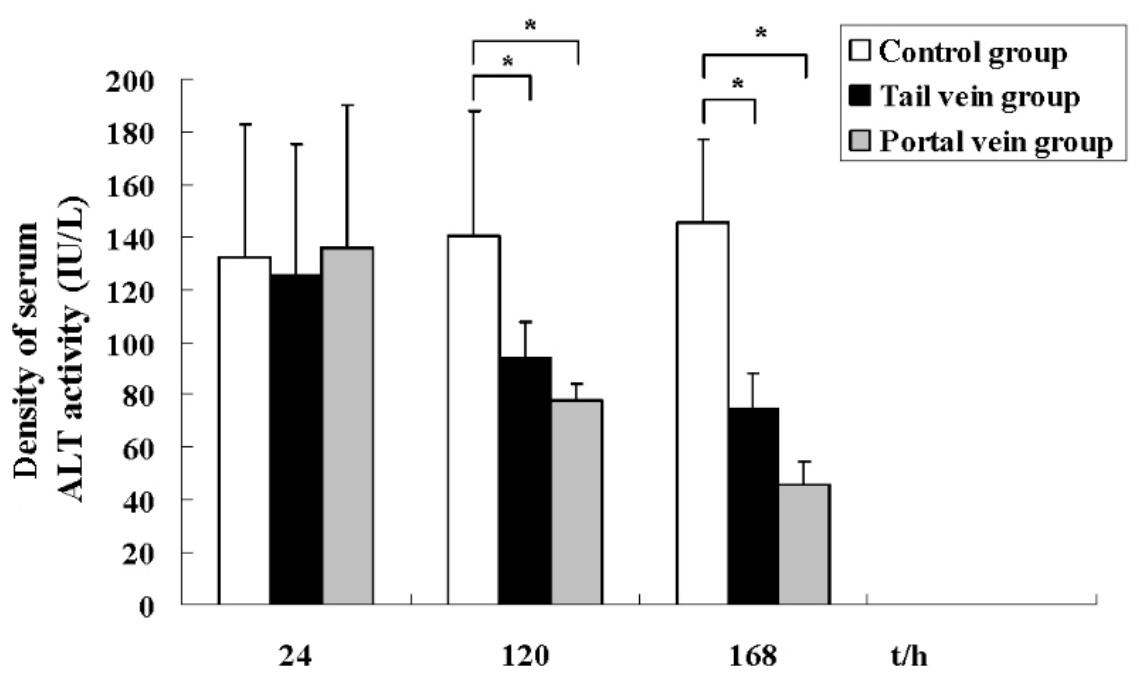

Figure 3. Density of serum ALT activity between the three groups. ${ }^{*} \mathrm{P}<0.05$.

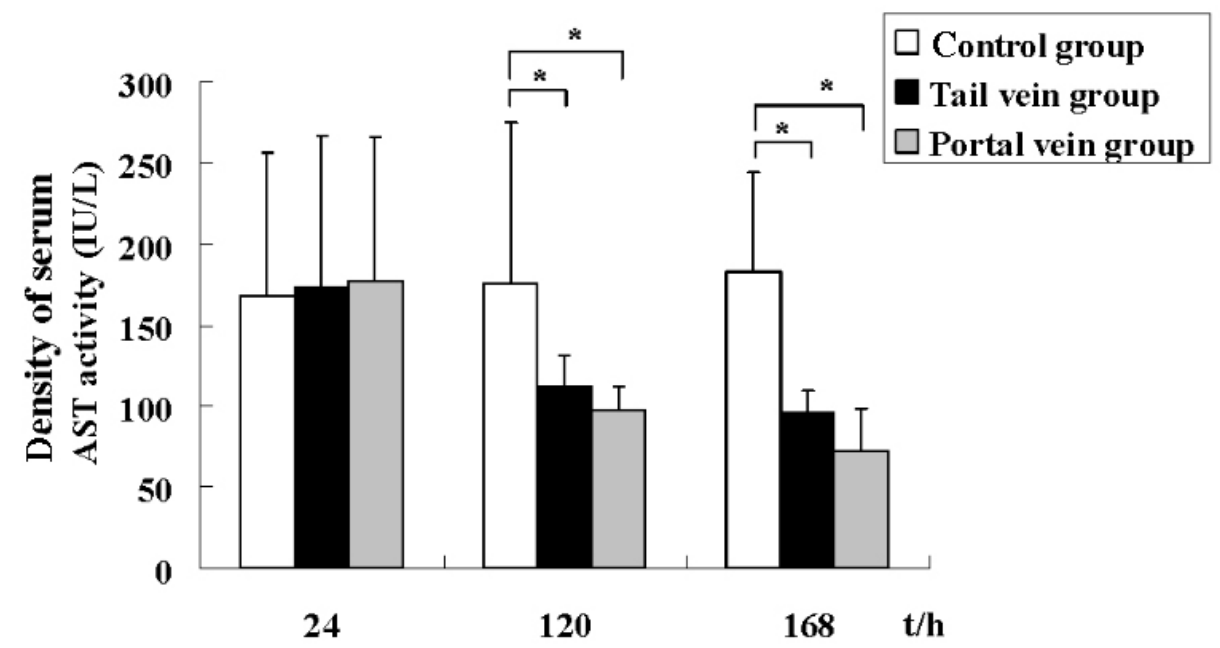

Figure 4. Density of serum AST activity between three groups. ${ }^{*} \mathrm{P}<0.05$.

\section{Post-transplant liver histopathology}

At $24 \mathrm{~h}$ after D-galactosamine injection, the liver tissue of the control group lost normal lobular structure, exhibiting hepatocyte cytoplasm edema, some regional ballooning, hepatocyte degeneration, a necrotic area filled with inflammatory cells and red blood cells, and inflammatory cell infiltration of the portal area (Figure 5A). The liver lobule structure of the normal rat was typical, with no symptoms, and the liver cells were arranged in cords (Figure 5B). At $24 \mathrm{~h}$ after transplantation, hepatocyte degeneration and inflammatory cell infiltration of the portal area were observed (Figure 5C and D). At 72 and $120 \mathrm{~h}$ after transplantation, the portal vein and tail 
vein transplantation groups showed extensive hepatocyte degeneration, mild piecemeal necrosis, and a significant reduction in inflammatory cell infiltration. Furthermore, we observed significant bile duct proliferation in the portal area (Figure 5E-H). At $168 \mathrm{~h}$ after transplantation, the lobule structure was gradually restored, and the number of inflammatory cells decreased (Figure 5I and J). H\&E staining showed significant morphological changes in the transplantation group compared to the control group ( $<0.05$; Table 2 and Figure 6). As shown in Figure 6, the pathological findings showed the presence of less inflammation, degeneration, and necrosis in the portal vein group compared to the tail vein group; however, there was no significant difference between the 2 groups.

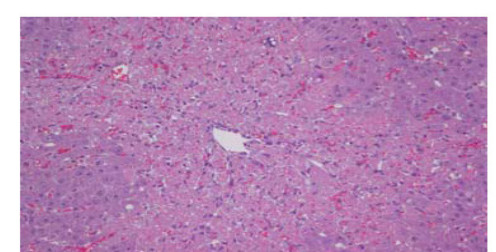

A control group $(\times 200)$

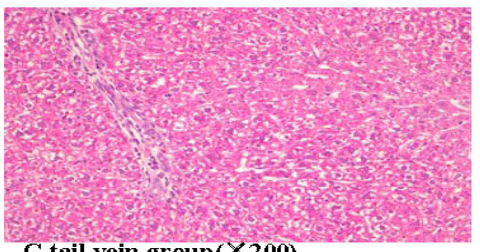

C tail vein group $(\times 200)$

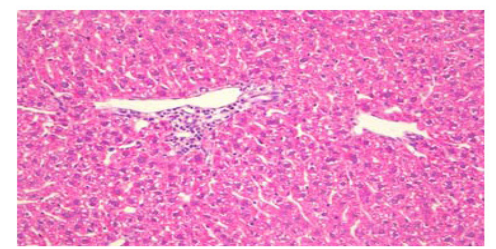

E tail vein group $(\times 200)$

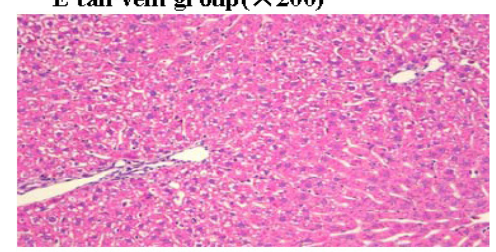

G Tail vein group $(\times 200)$

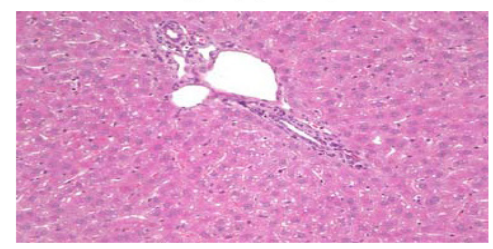

I Tail vein group $(\times 200)$

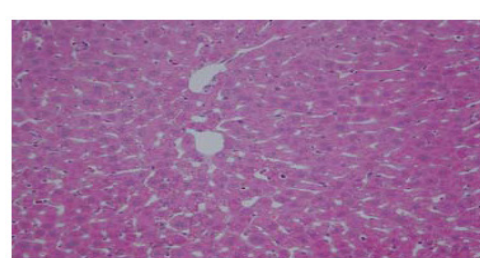

B normal liver $(\times 200)$

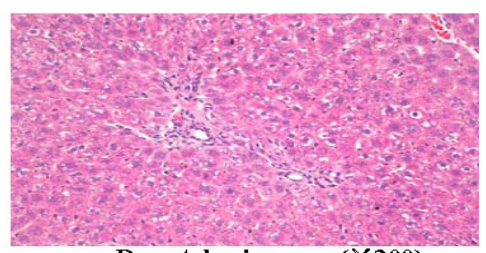

D portal vein group $(\times 200)$
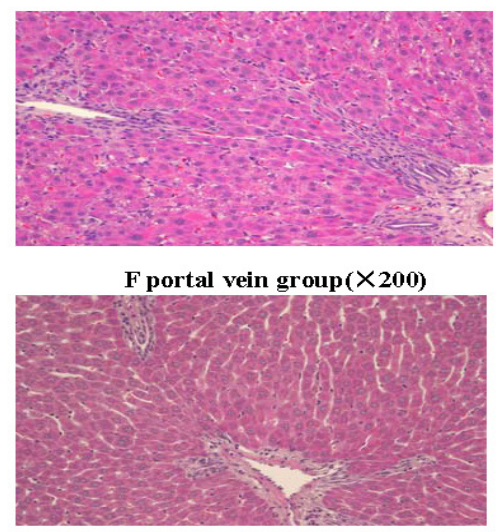

$H$ portal vein group $(\times 200)$

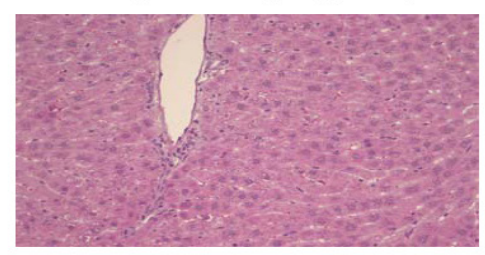

J Portal vein group $(\times 200)$

Figure 5. H\&E staining. 24 h: A. control group; B. normal liver; C. tail vein group; D. portal vein group; 72 h: E. tail vein group; F. portal vein group; 120 h: G. tail vein group; H. portal vein group; 168 h: I. tail vein group; J. portal vein group) (magnification 200X). 
Table 2. Inflammation of the liver activity at various times (Rank conversion mean $\pm \mathrm{SD}$ ).

\begin{tabular}{lcccc}
\hline Group & $24 \mathrm{~h}$ & $72 \mathrm{~h}$ & $120 \mathrm{~h}$ & $168 \mathrm{~h}$ \\
\hline Control group & $49.17 \pm 19.40$ & $46.41 \pm 17.06$ & $50.83 \pm 13.84$ & $55.25 \pm 6.73$ \\
Tail vein group & $46.42 \pm 17.06$ & $40.42 \pm 19.71^{\mathrm{a}}$ & $22.75 \pm 7.96^{\mathrm{a}}$ & $19.5 \pm 10.07^{\mathrm{a}}$ \\
Portal vein group & $42.00 \pm 18.53$ & $36.00 \pm 19.43^{\mathrm{b}}$ & $16.25 \pm 10.68^{\mathrm{b}}$ & $13.00 \pm 10.07^{\mathrm{b}}$ \\
\hline
\end{tabular}

${ }^{\mathrm{a}} \mathrm{P}<0.05 v s$ control group, ${ }^{\mathrm{b}} \mathrm{P}<0.05 v s$ control group.

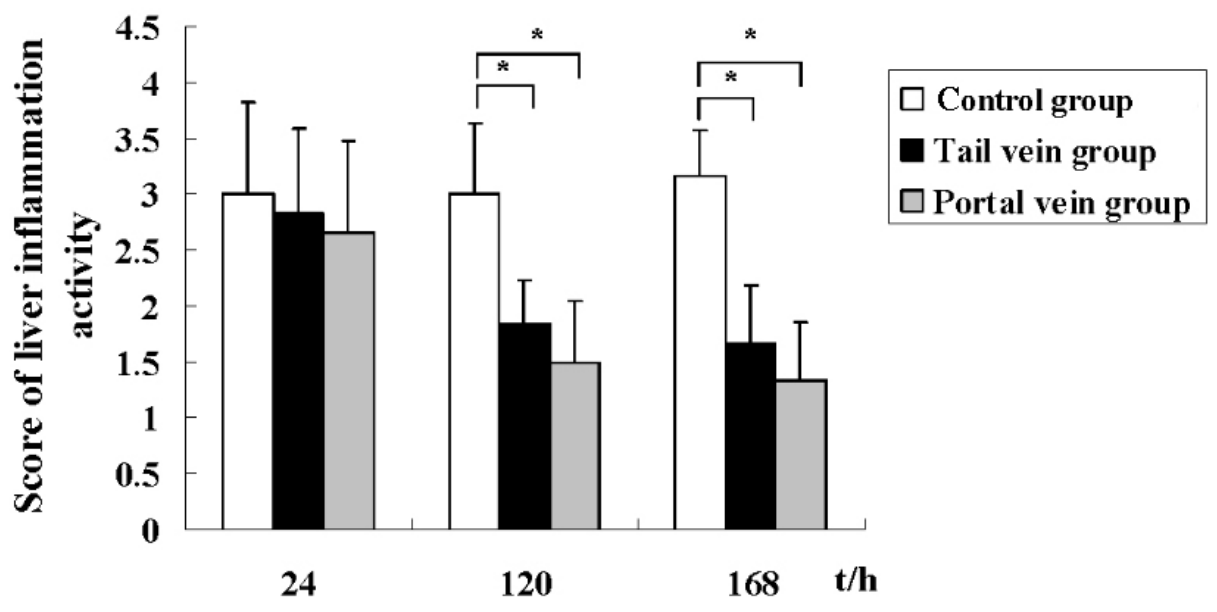

Figure 6. Score of liver inflammation between the three groups. ${ }^{*} \mathrm{P}<0.05$ vs control group.

\section{Inhibitory effect of BMSC transplantation on apoptosis}

The lobular architecture of the normal rat was typical, and the liver cell cord was radially arranged to the central venous structure. The presence of inflammatory cell infiltration, sinusoidal dilatation, and congestion in portal area was not observed. The hepatocyte cells of the control group and transplantation group exhibited different levels of apoptosis. The original hepatic lobule structure disappeared. Apoptotic cells had membrane integrity, nuclear changes, and pyknosis. Most apoptotic cells were located in the periphery of the necrotic area around the normal liver cells. Hepatocyte cell apoptosis was noticeably lower in the transplantation group compared to the control group at 120 and $168 \mathrm{~h}$ after transplantation $(\mathrm{P}<0.05)$. However, there was no significant difference between the portal vein group and the tail vein group (Table 3, Figures 7 and 8). These results confirm that BMSC transplantation inhibits apoptosis.

Table 3. Hepatocyte cell apoptosis at various times (Rank conversion mean $\pm \mathrm{SD}$ ).
\begin{tabular}{lcccc}
\hline Group & $24 \mathrm{~h}$ & $72 \mathrm{~h}$ & $120 \mathrm{~h}$ & $168 \mathrm{~h}$ \\
\hline Control group & $44.58 \pm 20.42$ & $48.50 \pm 14.24$ & $52.83 \pm 13.43$ & $57.17 \pm 10.61$ \\
Tail vein group & $44.17 \pm 13.43$ & $39.83 \pm 10.61$ & $24.17 \pm 20.57^{\mathrm{a}}$ & $18.17 \pm 13.97^{\mathrm{a}}$ \\
Portal vein group & $40.25 \pm 18.80$ & $35.92 \pm 15.67$ & $22.08 \pm 15.14^{\mathrm{b}}$ & $10.33 \pm 4.08^{\mathrm{b}}$ \\
\hline${ }^{\mathrm{a}} \mathrm{P}<0.05$ v control group, ${ }^{\mathrm{b}} \mathrm{P}<0.05$ v control group.
\end{tabular}



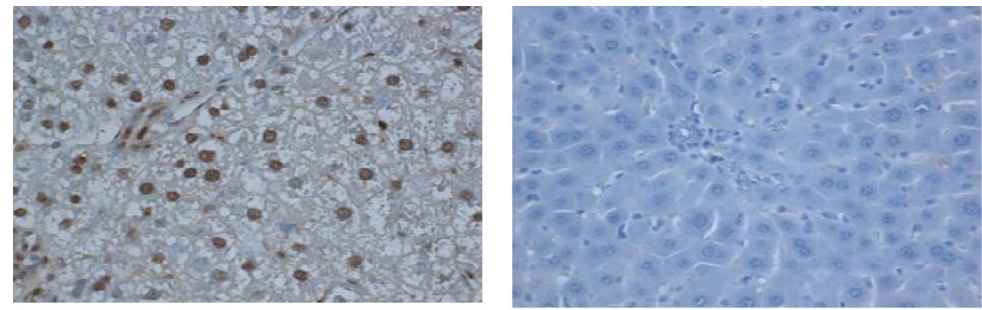

A The control group $(\times 400)$

B Normal liver $(x 400)$
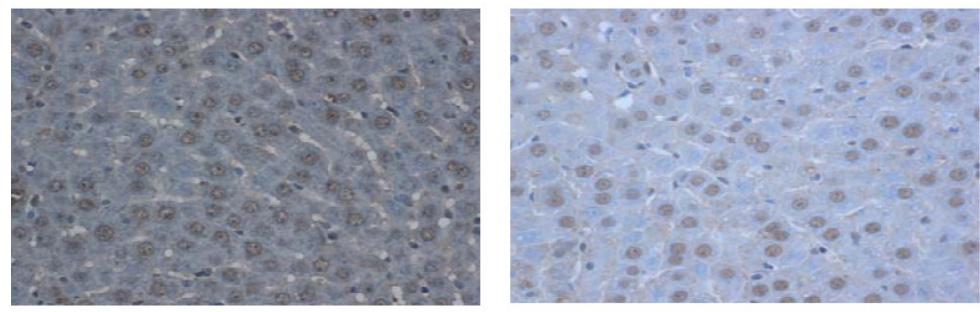

$C$ Tail vein group $(\times 400)$

D Portal vein group $(\times 400)$
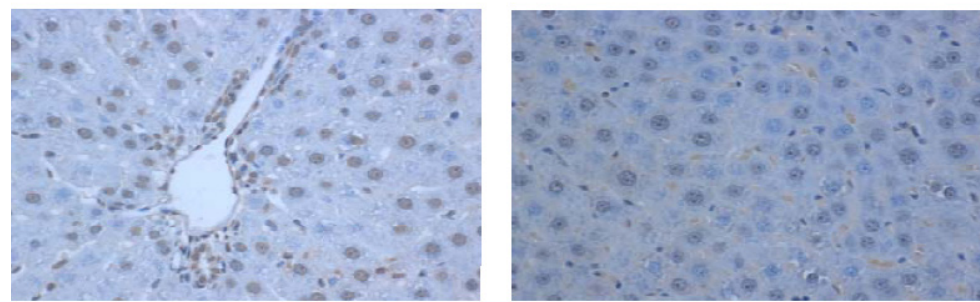

E Tail vein group $(\times 400)$

F Portal vein group $(\times 400)$

Figure 7. Hepatocyte cell apoptosis: TUNEL. A. Control group (24 h); B. normal liver; C. portal vein group (24 h); D. tail vein group (72 h); E. tail vein group (120 h); F. portal vein group (168 h) (magnification 400X).

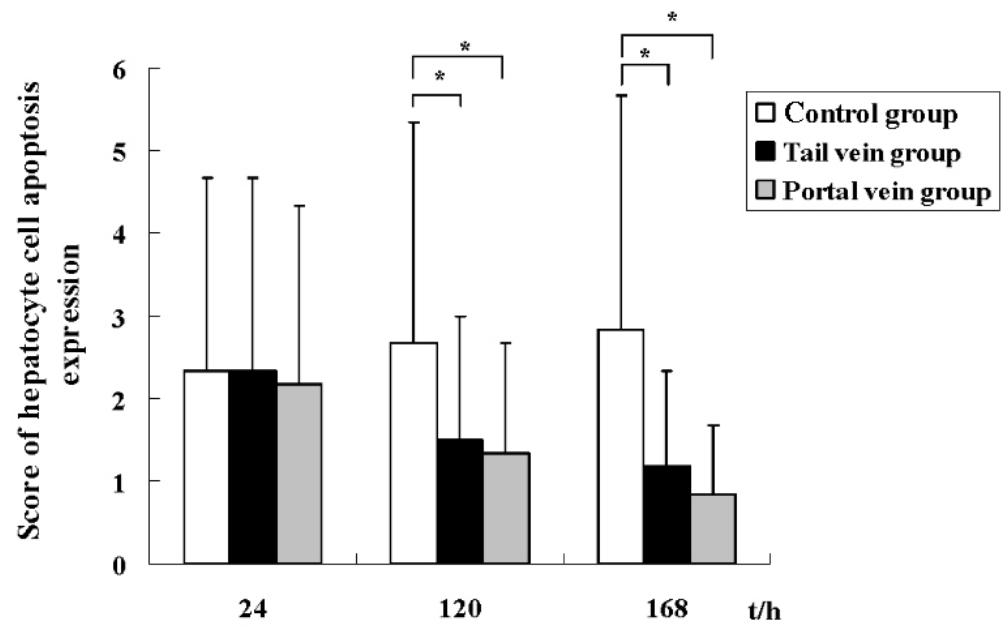

Figure 8. Score of hepatocyte cell apoptosis expression. $* \mathrm{P}<0.05$. 


\section{SDF-1 $\alpha$ and VEGF expression in the liver tissue}

\section{In situ hybridization and immunofluorescence}

In situ hybridization and immunofluorescence were employed to examine the expression of SDF-1 $\alpha$ mRNA (Figure 9) and VEGF protein levels (Figure 10). At 120 and $168 \mathrm{~h}$ after BMSC treatment, the expression of SDF- $1 \alpha$ mRNA and VEGF protein in the liver tissue was noticeably higher compared to the control group $(\mathrm{P}<0.05)$. These results indicate that there were highly significant correlations between SDF-1 $\alpha$ mRNA and VEGF protein levels in the liver tissue $(\mathrm{rs}=0.776, \mathrm{P}<0.05)$. SDF- $1 \alpha \mathrm{mRNA}$ and VEGF protein expression was higher in the portal vein group compared to the tail vein group; however, there were no significant differences between the 2 groups (Table 4, Figures 11 and 12).
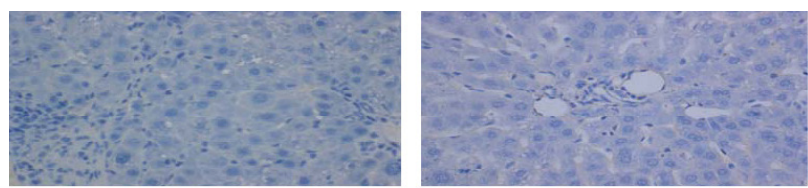

A SDF-1 a the control group $(\times 400) \quad$ B SDF-1 a Normal liver $(\times 400)$

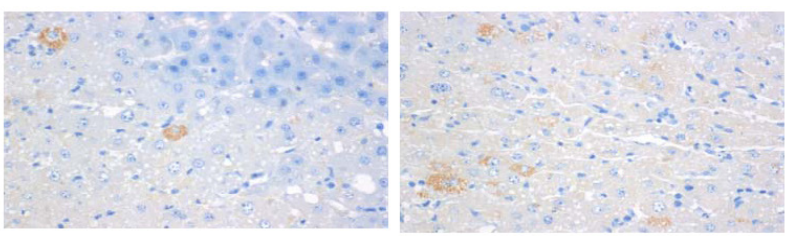

C SDF-1 a tail vein group $(\times 400) \quad$ D SDF-1 a portal vein group $\left(X_{400}\right)$
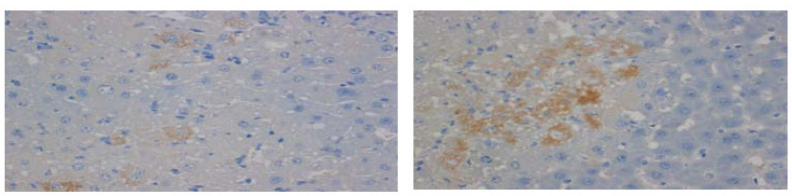

E SDF-1 a tail vein group $(\times 400)$

F SDF-1 a portal vein group $(\times 400)$
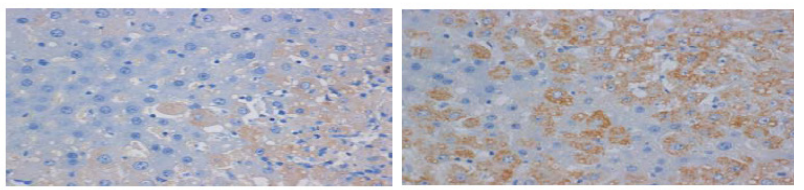

G SDF-1 $\propto$ tail vein group $(\times 400) \quad$ H SDF-1 $\alpha$ portal vein group $(\times 400)$

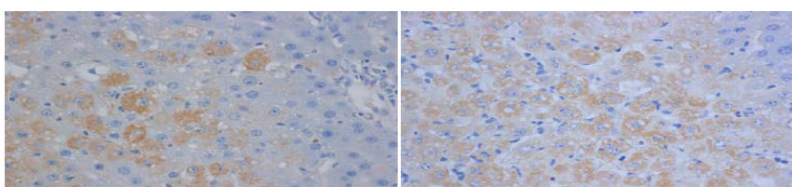

I SDF-1 a tail 1 vein group $(\times 400) \quad J$ SDF-1 a portal vein group $(\times 400)$

Figure 9. Expression of SDF-1 $\alpha$ mRNA in liver tissue detected by in situ hybridization. 24 h: A. the control group; B. negative control group; C. tail vein group; D. portal vein group; 72 h: E. tail vein group; F. portal vein group, 120 h: G. tail vein group; H. portal vein group; 168 h: I. tail vein group; J. portal vein group (magnification 400X). 


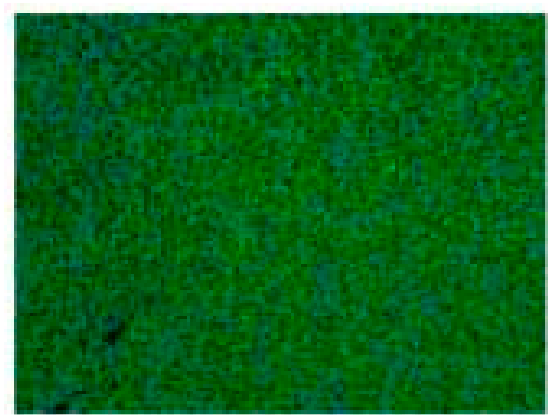

A VrGF control groap $(\times 100)$

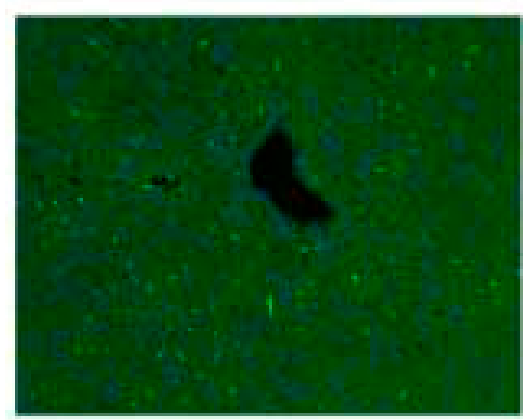

C VEGF tail veh Eroup $(100 \times)$

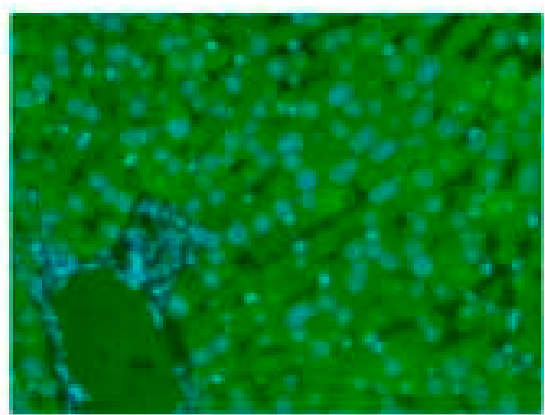

B VFGF nermal tive $(\times 200)$

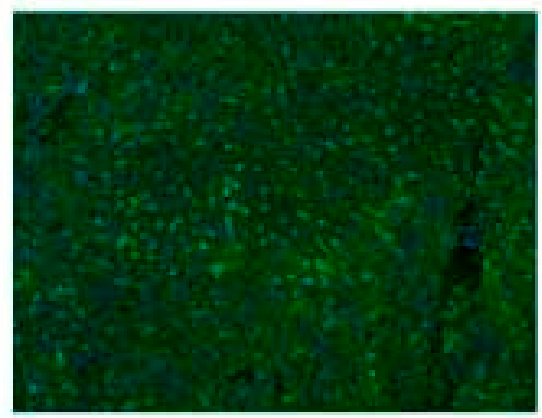

D VEGF patal vein uroap $(100 \times)$

Figure 10. Expression of VEGF protein in liver tissue detected by immunofluorescence. A. Control group. B. Normal liver. 128 h: C. tail vein group; D. portal vein group.

Table 4. Expression of SDF-1 $\alpha$ mRNA and VEGF protein in liver tissue (Rank conversion mean \pm SD).

\begin{tabular}{|c|c|c|c|c|c|c|}
\hline \multirow[t]{2}{*}{ Group } & \multicolumn{2}{|c|}{$24 \mathrm{~h}$} & \multicolumn{2}{|c|}{$120 \mathrm{~h}$} & \multicolumn{2}{|c|}{$168 \mathrm{~h}$} \\
\hline & SDF-1 $\alpha$ & VEGF & SDF-1 $\alpha$ & VEGF & SDF-1 $1 \alpha$ & VEGF \\
\hline Control group & $21.08 \pm 13.67$ & $18.67 \pm 11.88$ & $26.67 \pm 17.30$ & $30.08 \pm 17.16$ & $32.25 \pm 18.35$ & $33.92 \pm 14.39$ \\
\hline Tail vein group & $32.25 \pm 18.35$ & $22.42 \pm 19.06$ & $43.42 \pm 13.68^{\mathrm{a}}$ & $47.50 \pm 21.38^{\mathrm{a}}$ & $51.00 \pm 20.69^{\mathrm{a}}$ & $53.67 \pm 16.47^{\mathrm{a}}$ \\
\hline Portal vein group & $34.64 \pm 17.91$ & $27.43 \pm 11.22$ & $46.92 \pm 17.53^{b}$ & $55.08 \pm 11.75^{b}$ & $54.50 \pm 22.01^{\mathrm{b}}$ & $59.75 \pm 14.36^{b}$ \\
\hline
\end{tabular}

${ }^{\mathrm{a}} \mathrm{P}<0.05 v s$ control group, ${ }^{\mathrm{b}} \mathrm{P}<0.05 v s$ control group, ${ }^{\mathrm{a}, \mathrm{b}} \mathrm{rs}=0.776, \mathrm{P}<0.05$.

\section{Western blot analysis}

During the transplantation process, SDF-1 $\alpha$ and VEGF protein expression in the transplantation group was noticeably higher compared to the control group $(\mathrm{P}<0.05)$. Highly significant correlations were also present between SDF-1 $\alpha$ and VEGF protein expression ( $\mathrm{rs}=$ $0.584, \mathrm{P}<0.05$ ) (Table 5, Figures 13 and 14). SDF-1 $\alpha$ and VEGF protein levels were significantly higher in the BMSC portal vein group compared to the BMSC tail vein group (Figure $15, \mathrm{P}<0.05$ ). This result indicates that intraportal transplantation is a more effective pathway compared to tail vein transplantation. 


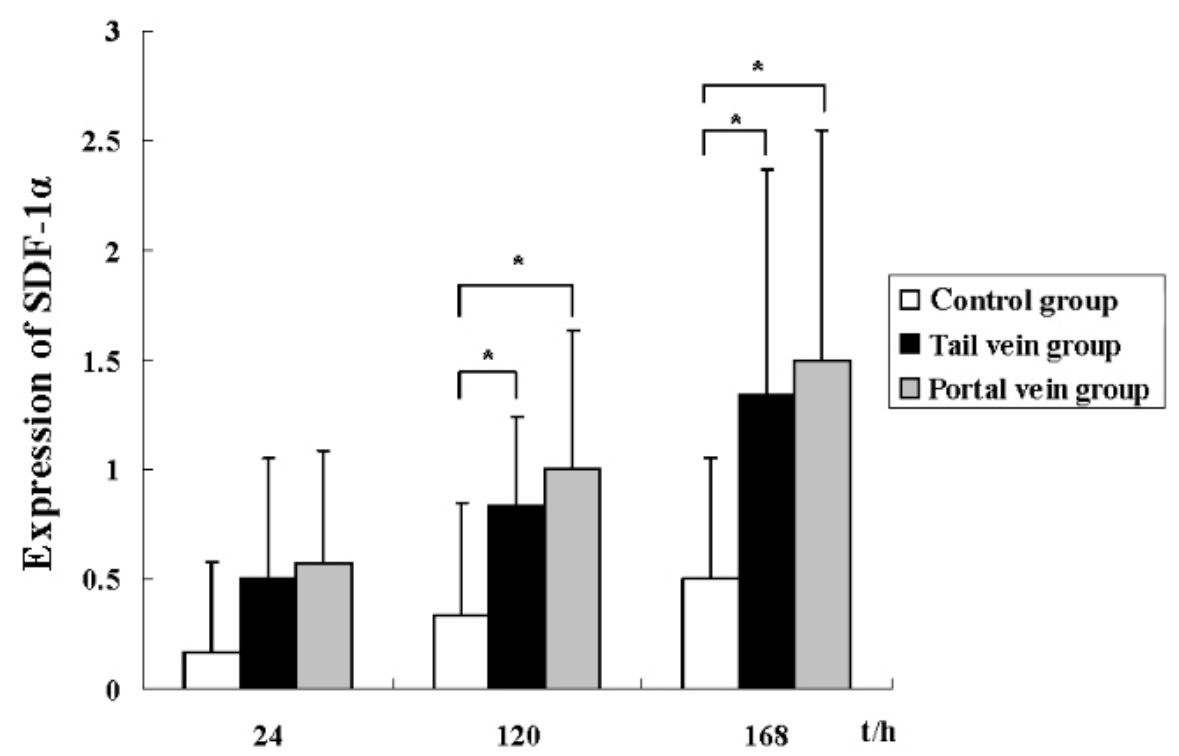

Figure 11. Expression of SDF-1 $\alpha$ between the three groups. $* \mathrm{P}<0.05$.

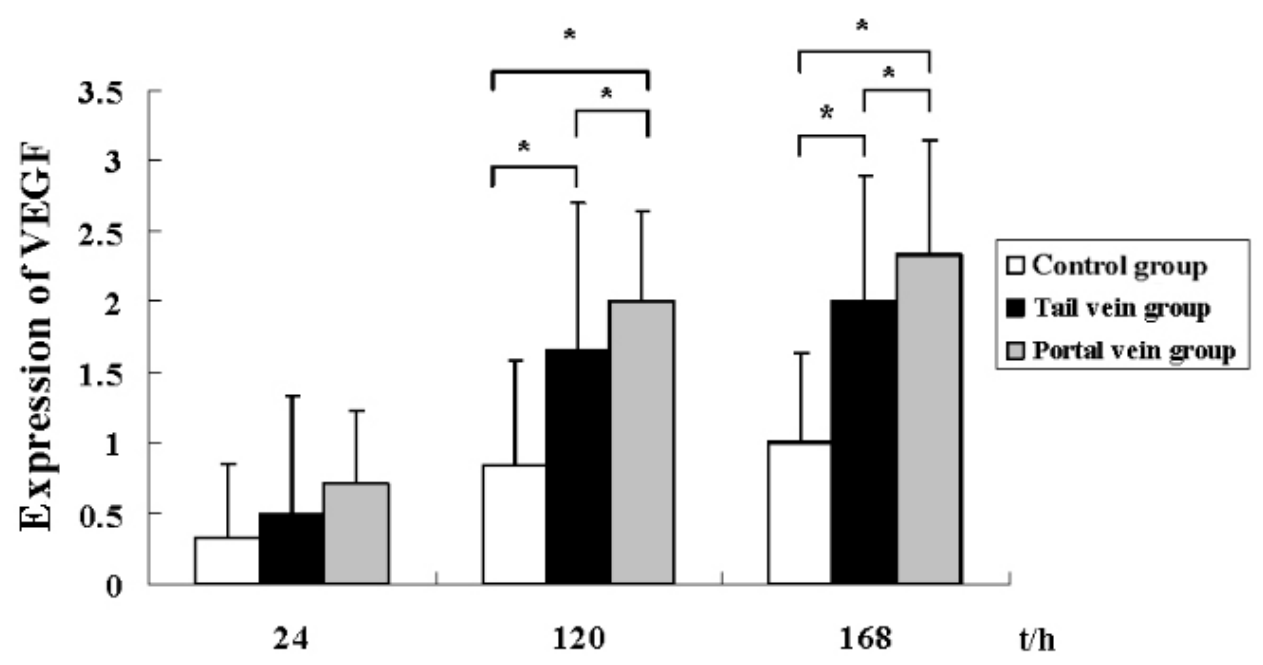

Figure 12. Expression of VEGF between the three groups. $* \mathrm{P}<0.05$.

Table 5. Expression of SDF-1 $\alpha$ and VEGF protein in liver tissue (mean $\pm \mathrm{SD}$ ).

\begin{tabular}{|c|c|c|c|c|c|c|}
\hline \multirow[t]{2}{*}{ Group } & \multicolumn{2}{|c|}{$24 \mathrm{~h}$} & \multicolumn{2}{|c|}{$120 \mathrm{~h}$} & \multicolumn{2}{|c|}{$168 \mathrm{~h}$} \\
\hline & SDF-1 $\alpha$ & VEGF & SDF-1 $1 \alpha^{c}$ & VEGF $^{d}$ & SDF-1 $1 \alpha^{c}$ & VEGF $^{d}$ \\
\hline Control group & $0.19 \pm 0.08$ & $0.87 \pm 0.34$ & $0.20 \pm 0.08$ & $1.50 \pm 0.48$ & $0.21 \pm 0.75$ & $1.57 \pm 058$ \\
\hline Tail vein group & $2.82 \pm 0.29$ & $2.07 \pm 0.143$ & $4.30 \pm 0.39^{\mathrm{a}}$ & $5.47 \pm 0.80^{\mathrm{a}}$ & $4.43 \pm 0.79^{\mathrm{a}}$ & $5.75 \pm 0.63^{\mathrm{a}}$ \\
\hline Portal vein group & $2.980 \pm 0.12$ & $4.38 \pm 0.17$ & $4.54 \pm 0.11^{\mathrm{b}}$ & $7.16 \pm 0.74^{b}$ & $5.28 \pm 0.44^{\mathrm{b}}$ & $7.80 \pm 0.54^{\mathrm{b}}$ \\
\hline
\end{tabular}

${ }^{a} \mathrm{P},{ }^{b} \mathrm{P}<0.05 v s$ control group, ${ }^{\mathrm{a}} \mathrm{P}<0.05 v s^{\mathrm{b}} \mathrm{P}$ (portal vein group), ${ }^{\mathrm{c}, \mathrm{d}} \mathrm{rs}=0.584, \mathrm{P}<0.05$. 


\section{$24 \mathrm{~h} \quad 72 \mathrm{~h} \quad 120 \mathrm{~h} \quad 168 \mathrm{~h}$}

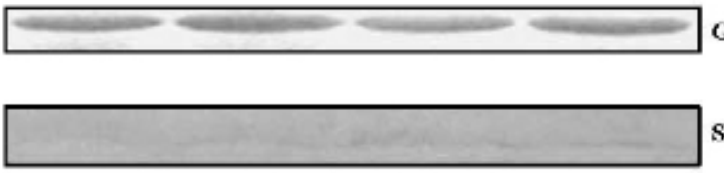

GAPDH $\quad 37 \mathrm{kDa}$

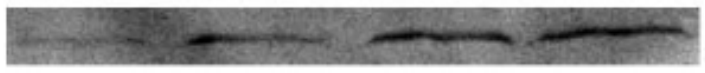

SDF-1 a tall vein group $\quad 9 \mathrm{kDa}$

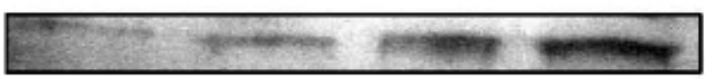

SDF-1 a portal vetn group 9 kDa

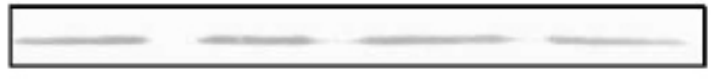

GAPDH

$37 \mathrm{kDa}$

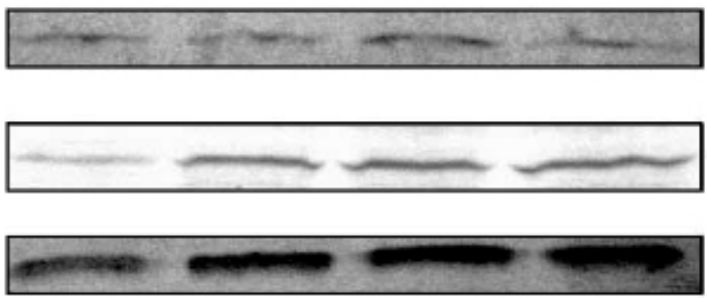

VEGF control group $21 \mathrm{kDa}$

VEGF tail vein group $21 \mathrm{kDa}$

Figure 13. Expression of SDF-1 $\alpha$ and VEGF in liver tissue detected by Western blot.

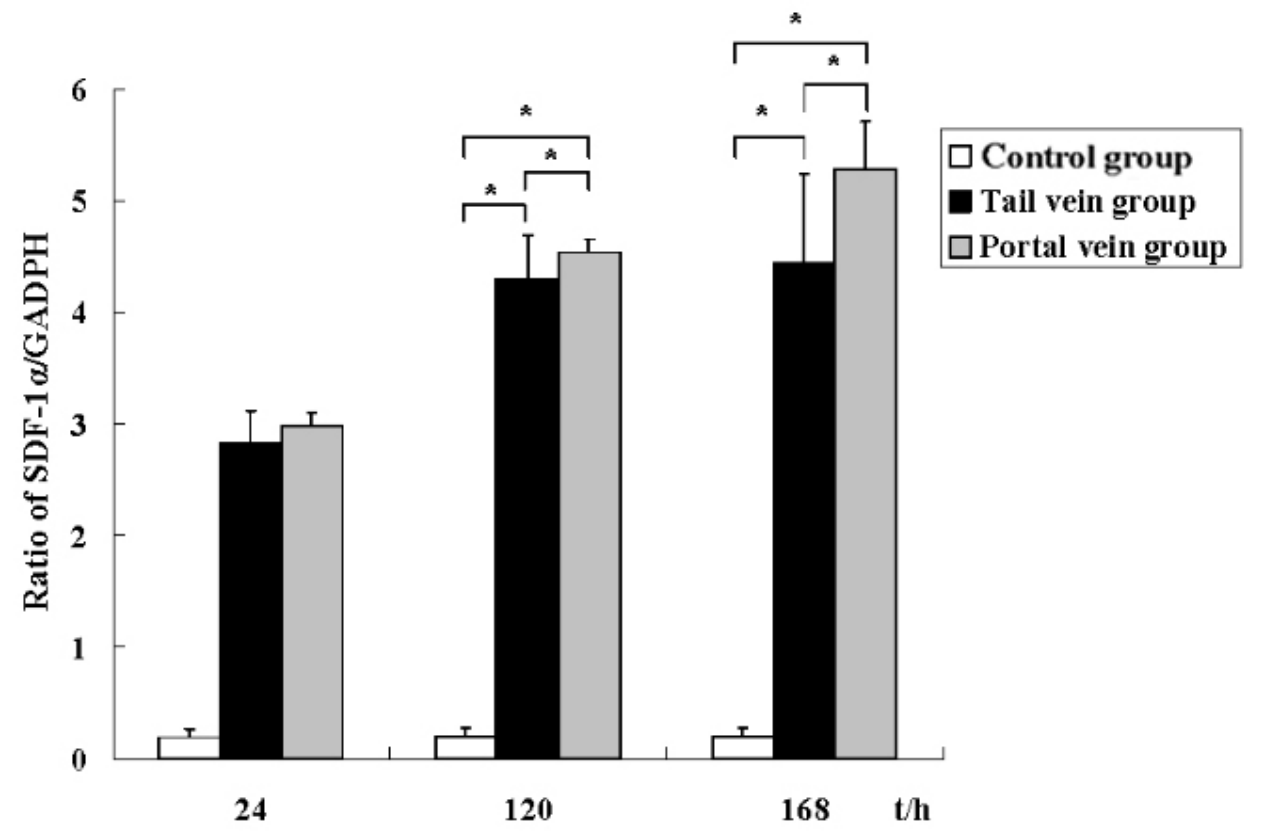

Figure 14. Ratio of SDF-1 $\alpha /$ GADPH between three groups. $* \mathrm{P}<0.05$. 


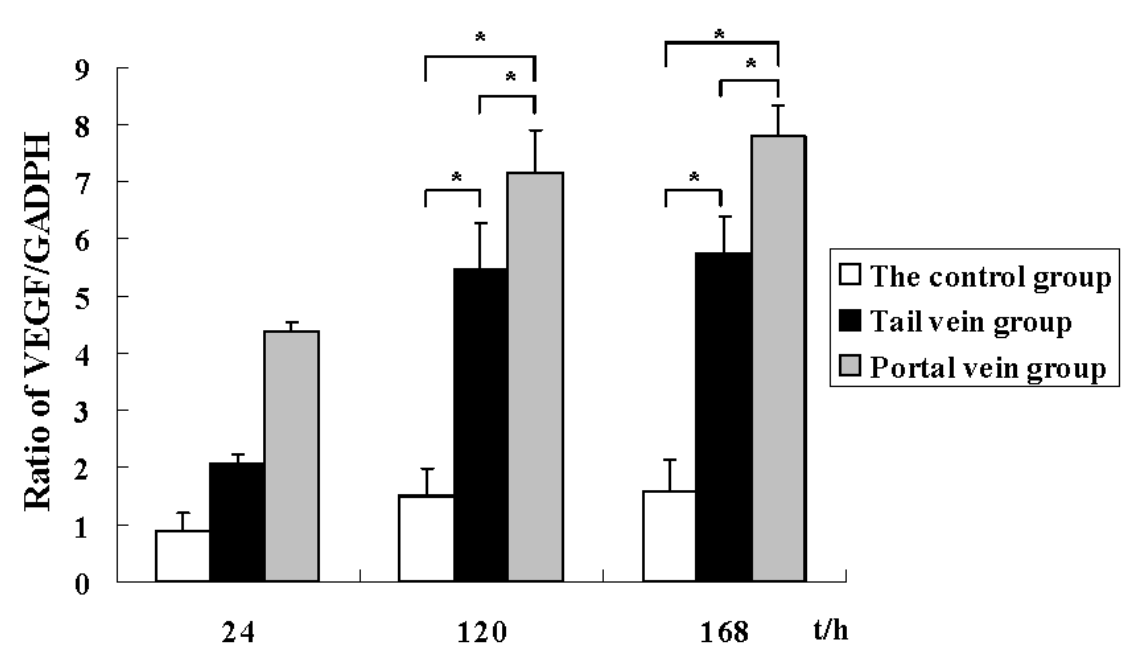

Figure 15. Ratio of VEGF/GADPH between the three groups. ${ }^{*} \mathrm{P}<0.05$.

\section{DISCUSSION}

BMSCs possess higher proliferation capacity and anti-senescence ability, in addition to the fundamental features of primary MSCs. BMSC therapy currently represents a promising strategy for ALF treatment (Sato et al., 2005; Cho et al., 2009). The present study demonstrated that BMSC transplantation attenuates liver damage by reducing the infiltration of inflammatory cells and inhibiting apoptosis. The experiments showed that BMSC transplantation generates a large increase in the number of liver and bile duct cells, subsequently improving liver function. The in vivo experiments also showed that BMSCs confer liver protective effects. These data indicate that BMSCs are key regulators of immune/ inflammatory responses in vivo, and present attractive candidates for the cell-based treatments of systemic inflammation-based disorders.

At present, the underlying mechanisms of ALF are assumed to involve a large area of liver necrosis, hepatocyte apoptosis, microcirculatory disturbance, cytokines, and other factors. Liver tissue is extremely sensitive to hypoxic-ischemic injury in ALF; hypoxia-ischemia and reperfusion injury can increase cell necrosis or apoptosis. Therefore, a reduction in the occurrence of apoptosis during cell transplantation is essential to enhance the effectiveness of cell transplantation (Kaplowitz, 2000; Rust and Gores, 2000; Jung et al., 2009). In vitro experiments have confirmed that MSCs are involved in the BMSC inhibition of hepatocyte apoptosis and that they promote the proliferation of liver cells. Previous studies have reported that BMSCs act in various ways through the paracrine secretion of cytokines and growth factors to promote regeneration. Such actions include the inhibition of inflammation and apoptosis, the activation of hepatic stellate cells, a reduction in the generation of the extracellular matrix, the degradation of intrahepatic excess in the extracellular matrix, and an improvement in liver fibrosis (Liu et al., 2009; Muraca, 2011). Our experiments showed that hepatocyte cell apoptosis noticeably decreases after transplantation. These results confirm that BMSC transplantation inhibits apoptosis.

BMSCs secrete numerous cytokines, including SDF-1 $\alpha$, VEGF, SDF-1, bFGF, IGF-1, 
and hepatocyte growth factor (Bhakta et al., 2006). SDF-1 $\alpha$ is a class of chemokine CXC subfamily involved in the migration of stem cells, in addition to cell proliferation and apoptosis. It has been reported that SDF- $1 \alpha$ has a mitogenic and anti-apoptotic role. SDF- $1 \alpha$ acts as a chemo-attractant to promote the migration of stem cells and strengthen their locomotory capacity (Thelen and Thelen, 2008; Wang et al., 2012). When stem cells migrate to the target tissue, SDF-1 $\alpha$ facilitates their adhesion to fibrinogen, fibronectin, interstitium, and endotheliocytes (Burns et al., 2006). Subsequently, the cells that adhere to the blood vessel endothelium, permeate the vessel walls to access the target tissue. With the help of SDF-1 $\alpha$, the secretion of more MMP-9, NO, and VEGF promote the mobilization of stem cells (Tang et al., 2007; Kuang et al., 2008; Gao et al., 2010; Huang et al., 2010; Takamiya et al., 2011). These paracrine factors, especially VEGF, are important for maintaining or improving normal vascular endothelial function. Hyperoxia-induced downregulation of VEGF has been reported in the rat retina and has been found to be associated with the death of endothelial cells by apoptosis (Alon et al., 1995; Ma et al., 2005). TUNEL staining demonstrated that the tendency for apoptotic cells to decline is associated with an increase in SDF-1 $\alpha$ and VEGF. These experiments show that if the expression of SDF-1 $\alpha$ and VEGF increases, the amount of apoptotic cells decreases. These results confirm that both VEGF and SDF-1 $\alpha$ have anti-apoptotic functions, with SDF-1 $\alpha$ promoting cell proliferation and differentiation. The present study showed that SDF-1 $\alpha$ and VEGF interact; whereby, VEGF induces the expression of SDF- $1 \alpha$ in liver cells, while SDF- $1 \alpha$ induces VEGF expression. This phenomenon indicates that the SDF-1 $\alpha /$ VEGF axis is a viable mode for stem cell therapy targeting ALF; however, precision is required regarding the timing and quantity of application of the 2 cytokines.

As expected, the expression of SDF- $1 \alpha$ and VEGF significantly increased after BMSC transplantation. Higher VEGF expression levels were correlated with elevated SDF-1 $\alpha$ expression in the transplantation group, indicating that SDF-1 $\alpha$ promotes the homing of BMSCs to damaged liver tissue. The results of the gene expression analysis support the hypothesis that BMSCs are dynamic cells that are activated by an inflammatory environment, and that they are able to alter their characteristics (genome and secretome) when providing immunomodulation. These results could facilitate the characterization of the dynamics, duration, and trajectory of systemic inflammatory response, and permit the identification of possible targets for therapies and possible predictive biomarkers. In both the portal vein and tail vein groups, SDF-1 $\alpha$ and VEGF had similar levels of expression but with different effects. SDF-1 $\alpha$ and VEGF protein levels were significantly higher in the BMSC portal vein group compared to the BMSCs tail vein group. This finding indicates that intraportal transplantation provides a more effective pathway compared to tail vein transplantation.

In summary, we demonstrated that BMSC transplantation is of therapeutic benefit for treating ALF by providing anti-inflammatory and anti-apoptotic effects. BMSCs proved to be a potential and valuable alternative means of treating ALF. However, further studies are required to clarify the exact mechanism and to improve the effectiveness of BMSCs at reducing liver inflammation, as well as improving the quality of life of patients and prolonging their survival time.

\section{Conflicts of interest}

The authors declare no conflict of interest. 


\section{ACKNOWLEDGMENTS}

We thank the laboratory staff of Key Laboratory of Xinjiang Medical Animal Model Research for their ongoing support. We thank Mrs Hui Liu, Qing Wei, and Mr. Shutao Zheng for their help with cell irradiation and cell transplantation and biopsy procedures. Research supported by grants from the Key Laboratory of Xinjiang Medical Animal Model Research of China (Grant \#XJDX1103-2012-01), Xinjiang Autonomous Region Key Disciplines (Medicine) Building Fund.

\section{REFERENCES}

Alison MR, Islam S and Lim S (2009). Stem cells in liver regeneration, fibrosis and cancer: the good, the bad and the ugly. J. Pathol. 217: 282-298.

Alon T, Hemo I, Itin A, Pe'er J, et al. (1995). Vascular endothelial growth factor acts as a survival factor for newly formed retinal vessels and has implications for retinopathy of prematurity. Nat. Med. 1: 1024-1028.

Askari AT, Unzek S, Popovic ZB, Goldman CK, et al. (2003). Effect of stromal-cell-derived factor 1 on stem-cell homing and tissue regeneration in ischaemic cardiomyopathy. Lancet 362: 697-703.

Bhakta S, Hong P and Koc O (2006). The surface adhesion molecule CXCR4 stimulates mesenchymal stem cell migration to stromal cell-derived factor-1 in vitro but does not decrease apoptosis under serum deprivation. Cardiovasc. Revasc. Med. 7: 19-24.

Burns JM, Summers BC, Wang Y, Melikian A, et al. (2006). A novel chemokine receptor for SDF-1 and I-TAC involved in cell survival, cell adhesion, and tumor development. J. Exp. Med. 203: 2201-2213.

Cho KA, Ju SY, Cho SJ, Jung YJ, et al. (2009). Mesenchymal stem cells showed the highest potential for the regeneration of injured liver tissue compared with other subpopulations of the bone marrow. Cell Biol. Int. 33: 772-777.

Enns GM and Millan MT (2008). Cell-based therapies for metabolic liver disease. Mol. Genet. Metab. 95: 3-10.

Gao E, Lei YH, Shang X, Huang ZM, et al. (2010). A novel and efficient model of coronary artery ligation and myocardial infarction in the mouse. Circ. Res. 107: 1445-1453.

Huang PH, Chen YH, Tsai HY, Chen JS, et al. (2010). Intake of red wine increases the number and functional capacity of circulating endothelial progenitor cells by enhancing nitric oxide bioavailability. Arterioscler. Thromb. Vasc. Biol. 30: 869-877.

Jung KH, Shin HP, Lee S, Lim YJ, et al. (2009). Effect of human umbilical cord blood-derived mesenchymal stem cells in a cirrhotic rat model. Liver Int. 29: 898-909.

Kaplowitz N (2000). Mechanisms of liver cell injury. J. Hepatol. 32: 39-47.

Kim WR and Kremers WK (2008). Benefits of "the benefit model" in liver transplantation. Hepatology 48: 697-698.

Kuang D, Zhao X, Xiao G, Ni J, et al. (2008). Stem cell factor/c-kit signaling mediated cardiac stem cell migration via activation of p38 MAPK. Basic Res. Cardiol. 103: 265-273.

Lee WM, Squires RH Jr, Nyberg SL, Doo E, et al. (2008). Acute liver failure: Summary of a workshop. Hepatology 47 : 1401-1415.

Liu F, Liu ZD, Wu N, Cong X, et al. (2009). Transplanted endothelial progenitor cells ameliorate carbon tetrachlorideinduced liver cirrhosis in rats. Liver Transpl. 15: 1092-1100.

Los M, Voest EE and Borel Rinkes IH (2005). VEGF as a target of therapy in gastrointestinal oncology. Dig. Surg. 22: 282-293.

Lysy PA, Campard D, Smets F, Najimi M, et al. (2008). Stem cells for liver tissue repair: current knowledge and perspectives. World J. Gastroenterol. 14: 864-875.

Ma J, Ge J, Zhang S, Sun A, et al. (2005). Time course of myocardial stromal cell-derived factor 1 expression and beneficial effects of intravenously administered bone marrow stem cells in rats with experimental myocardial infarction. Basic Res. Cardiol. 100: 217-223.

Masson S, Harrison DJ, Plevris JN and Newsome PN (2004). Potential of hematopoietic stem cell therapy in hepatology: a critical review. Stem Cells 22: 897-907.

Muraca M (2011). Evolving concepts in cell therapy of liver disease and current clinical perspectives. Dig. Liver Dis. 43: 180-187.

Oertel M and Shafritz DA (2008). Stem cells, cell transplantation and liver repopulation. Biochim. Biophys. Acta 1782: 61-74.

Rust C and Gores GJ (2000). Apoptosis and liver disease. Am. J. Med. 108: 567-574. 
Sato Y, Araki H, Kato J, Nakamura K, et al. (2005). Human mesenchymal stem cells xenografted directly to rat liver are differentiated into human hepatocytes without fusion. Blood 106: 756-763.

Stutchfield BM, Forbes SJ and Wigmore SJ (2010). Prospects for stem cell transplantation in the treatment of hepatic disease. Liver Transpl. 16: 827-836.

Takamiya M, Haider KH and Ashraf M (2011). Identification and characterization of a novel multipotent sub-population of Sca-1(+) cardiac progenitor cells for myocardial regeneration. PLoS One 6: e25265.

Tang YL, Shen L, Qian K and Phillips MI (2007). A novel two-step procedure to expand cardiac Sca-1+ cells clonally. Biochem. Biophys. Res. Commun. 359: 877-883.

Thelen M and Thelen S (2008). CXCR7, CXCR4 and CXCL12: an eccentric trio? J. Neuroimmunol. 198: 9-13.

Wang H, Yin Y, Li W, Zhao X, et al. (2012). Over-expression of PDGFR-beta promotes PDGF-induced proliferation, migration, and angiogenesis of EPCs through PI3K/Akt signaling pathway. PLoS One 7: e30503. 